Urška Sešek

UDK 81'243:373.3(497.4)

University of Ljubljana

DOI: 10.4312/linguistica.54.1.31-46

Janez Skela

University of Ljubljana

Tomi Deutsch

The National Education Institute of the Republic of Slovenia*

\title{
THE EUROPEAN LANGUAGE PORTFOLIO (ELP) IN SLOVENIAN PRIMARY EDUCATION: THE TEACHERS' PERSPECTIVE
}

\section{THE EUROPEAN LANGUAGE PORTFOLIO: THE BACKGROUND}

Since its inception, the European Union has been making efforts to preserve its linguistic and cultural diversity, and to equip its citizens with communicative competences needed by a highly-mobile and flexible economy and society. The main institution in charge of promoting the multilingualism of individuals and the linguistic/cultural plurality of societies, through educational projects, has been the Council of Europe (Mitchell 2009: 90). The 1995 European Commission "M+ 2 policy", stating that each individual should develop communicative ability in at least two foreign languages (European Commission 1995: 47), was the basis for two of the key projects of the Council of Europe: the Common European Framework of Reference for Languages (CEFR 2001) and the European Language Portfolio (ELP). These two tools were developed in parallel, and are closely related. The CEFR is a description of the aspects of language, its use and the underlying competences - a comprehensive document meant to serve as an aid in developing curricula, textbooks and tests for the teaching and learning of any language.

The ELP is CEFR's counterpart, a materials package for language learners and teachers that transfers, into classroom practice, the key ideas of the CEFR: language as part of a complex set of competences developed and used across cultures, learner autonomy and life-long learning (Stoicheva et al. 2009: 4; Little et al. 2011: 5). With its workbook format, the ELP enables language learners to record and reflect on their language learning and intercultural experiences, formal and informal, over a period of time. Another important aspect of the ELP is that its use can be guided by a teacher or independent of one - self-directedness is a key feature of its design. As a record of an individual's language profile, it is also a personal document that can serve as proof of a person's experience and competences for the needs of various types of mobility across Europe and beyond.

* Authors' addresses: Filozofska fakulteta, Univerza v Ljubljani, Aškerčeva 2, 1000 Ljubljana, Slovenia. Zavod RS za šolstvo, OE Maribor, Trg revolucije 7, 2000 Maribor, Slovenia. E-mails: urska.sesek@guest.arnes.si, janez.skela@guest.arnes.si, Tomi.Deutsch@zrss.si. 
The ELP was conceived in 1991, and then shaped within the Council of Europe's project, Language Learning for European citizenship. From 1998 to 2000, versions of the ELP were produced and piloted in 15 member states. The ELP was adapted for users of all ages, and for different educational contexts: primary, secondary, vocational, university and adult. The pilot projects involved approximately 30,000 learners and 2,000 teachers. The project report (Schärer 2000) synthesized the findings of all the pilot projects, and made recommendations for further activities. The overall conclusion was that the ELP is a feasible learning and teaching tool, which addresses the key educational issues in Europe, and fosters the aims of the Council of Europe.

After 2000, large-scale implementation began, and a validation committee was set up by the Council of Europe, to ensure that all versions of the ELP conformed with the "ELP Principles and Guidelines". Only validated ELPs could use the official ELP logo but, at the same time, the developers had room to adapt their models to the needs of specific contexts. In 2001, the European Year of Languages, a seminar was held in Portugal to officially launch the ELP. Between 2001 and 2009, seven further seminars were organised, and the Council of Europe published various supports for ELP developers (e.g. Schneider and Lenz 2001), teachers and teacher trainers (Little and Perclová 2001). By 2011, 118 ELPs, from 32 member states, had been validated. ELPs have been designed for, and implemented, in all educational contexts: primary, lower and upper secondary, vocational, adult, further and tertiary. In 2007, the rapporteur general estimated that 2.5 million individual ELPs had been produced and/or distributed (Schärer 2007).

\section{THE ELP: ITS STRUCTURE, AIMS AND IMPLEMENTATION}

The general idea of a portfolio - as a folder containing selected samples of a person's work to show to potential customers, employers and others - was modified to suit the mission of the ELP. Its three obligatory components include:

- a Language Passport, a record of the user's second/foreign languages (L2s) learnt, formal language qualifications achieved, significant experiences of L2 use, and a self-assessment of the user's current proficiency in the L2s listed;

- a Language Biography, used to set language learning targets, monitor progress, and record and reflect on important language learning and intercultural experiences;

- a Dossier, presenting evidence of the user's proficiency in the selected language(s).

As can be seen from this description, the ELP has a two-fold function (Ushioda and Ridley 2002: 2): a reporting function (the Language Passport and the Dossier) and a pedagogical function (the Language Biography and the Dossier). A key feature of the ELP is self-assessment - all of its sections require some form of this. The various versions of the ELP approach this somewhat differently, but they all derive their categories from the CEFR's six levels of proficiency in the five communicative skills/activities: listening, reading, spoken interaction, spoken production, and writing. The self-assessment mostly takes the form of grids, scales or checklists, adapted to the users' age and context, the "can-do" statements being the most common descriptor format. 
In its documentary function, the ELP supplements certificates and diplomas, and allows the owner to document informal language learning. Users engage in continuous self-assessment of their language skills, and express it in widely-acknowledged terms. Its pedagogical function is to promote plurilingualism, raise cultural awareness, and enhance the language learning processes by increasing the users' learner autonomy. The process of compiling an ELP namely engages learners in thinking about their learning process, directing and sustaining it. We can say that effective use of the ELP, in both its functions, hinges on an on-going process of self-reflection.

The pan-European implementation of the ELP so far has mostly taken place within projects initiated by Ministries of Education or, in some cases, institutions at a regional or local level (Stoicheva et al. 2009: 7, 8). Examples range from trans-national ELPs, such as the ALTE-EAQUALS model, to various national ELPs for public schools and offshoots, such as the Professional European Language Portfolio, the CROMO (CROMO 2007), a cross-border project of Austria, Italy and Slovenia, and the European Portfolio for Student Teachers of Languages by Newby et al. (2007). In addition, there are many local, localized and in-house ELP models being developed around Europe, which may or may not comply with the requirements of the Council of Europe. The ELP has had a considerable impact on different aspects of foreign language learning and teaching, across Europe and beyond (for an impact study, see Stoicheva et al. 2009).

\section{THE ELP IN SLOVENIA: THE CONTEXT OF THE STUDY}

In Slovenia, five ELP models have been developed so far for different age groups:

- lower primary level (ages 6-10), validated in 2011 (Čok et al. 2011);

- upper primary level (ages 11-15), validated in 2004 (Skela and Holc 2006);

- secondary level (ages 15-19), validated in 2006 (Puklavec et al. 2006);

- adult learners (16+), validated in 2010 (Amič et al. 2010);

- an experimental ELP for university students (Troha et al. 2000).

Slovenia was among the first countries to join the Council of Europe's ELP project. Between 1998 and 2000, two ELP models (Čok et al. 1999 and Skela et al. 2000) were piloted, with 634 students and 20 teachers (Schärer 2000: 63-64). The main findings of the piloting work were similar to those found in other countries, and included in Schärer's 2000 report. The ELP was considered an interesting and beneficial tool, by both learners and teachers. Learner self-assessment was considered an important innovation and there were positive effects on learner motivation. The problems and questions included: how to relate the ELP to formal assessment, how to integrate the ELP with the curriculum and textbooks used and how to make enough time for the ELP. Also, it became clear that both learners and teachers needed certain training to make the most of the ELP.

After the piloting phase, implementation began in the school year 2001/2002. As an ELP model for secondary schools was not available yet, only primary schools participated (Godunc 2012: 61-63). The implementation was evaluated using standard 
questionnaires, discussions and teacher reports at seminars, and samples of learner-produced ELPs. The data collected was again sent to the rapporteur general, and supported similar conclusions as had been made during the previous piloting projects. Overall, the numbers of ELP users in Slovenia grew to 2,150 in the school year 2003/2004 (Schärer 2004: 47). To support the participating teachers in this period of experimental implementation, the Slovenian Ministry of Education organised many seminars, including a series aimed at training a small group of teachers as ELP trainers.

In 2006, a large-scale research project was launched by the Ministry of Education, to conduct a thorough and objective empirical evaluation of the ELP in Slovenian primary and secondary schools, over a three-year period (Holc 2012: 69-70). The project entitled "Uvajanje in spremljava Evropskega jezikovnega listovnika v OŠ in Sડ̆" ("Introduction and Evaluation of the ELP in Primary and Secondary Schools") included 72 primary schools in the years 2006-2009, and 42 secondary schools in the years 2007-2010 (ibid.: 71). The objective of the study was to find out the scope of the use of the ELP (number of users, types of contexts etc.), how it was received by learners and teachers, the issues concerning its implementation and, most importantly, what impact the use of the ELP was perceived to have. Because of the scope of this project, we present in this paper only the research done in primary schools, where the foundations of language learning are laid.

The Ministry of Education invited the schools to participate, and individual language teachers were able to choose whether to get on board (a minimal stimulation in the form of promotion credits was offered). The schools were then provided with the needed number of copies of the two validated versions of the ELP for Slovenian primary schools (Čok et al. 1999 for younger learners, and Skela and Holc 2006, for learners aged 11 to 15). The participating teachers selected the classes which would work with the ELP. The teachers and their selected classes were then obliged to participate in the monitoring. Because of the nature of the ELP as a complex innovation, the impact of which involves a considerable shift of beliefs and attitudes that can only unfold over a period of time, direct methods of impact study, such as experiments, classroom observation or external testing of learner competences, were deemed less appropriate than an exploration of teachers' and learners' perceptions. Thus, the main research method used was a survey of all the participating teachers and learners. As presenting the entire mass of data (from two teacher surveys and one learner survey, altogether over 800 responses) would exceed the scope of this article, we present here the results of the teacher surveys. Additional reasons for focusing on the teachers' perspective include the quality of data (the data gained from the teachers, who worked with the ELP voluntarily, is somewhat more reliable than the students' data) and the fact that it is the teachers who are the carriers of pedagogical innovation.

The specific research questions addressed through this sub-study were:

1. Who are the users of the ELPs in Slovenia, and what is the context of their ELP use? (number of teachers, grade levels and number of classes, frequency of use, teacher preparation); 
2. What are the teachers' perceptions of the quality of the ELPs used? (appropriateness for use with target groups, usefulness of the components, effectiveness in its different functions, and teacher satisfaction with the content, particularly the language competence scales);

3. What effect does the ELP have on teaching? (in general, on lesson planning and on teacher teamwork);

4. What effect does the ELP have on learning? (in general and on learners' capacity for self-assessment and learner autonomy);

5. What are the problems with the ELP, and what is its potential for full-scale use?

\section{METHODOLOGY}

The first phase of the study in primary schools, carried out in 2008, included teachers only, but at two different levels: the lower-primary $\left(1^{\text {st }}-5^{\text {th }}\right.$ grade, 18 participants $)$ and upper-primary $\left(6^{\text {th }}-9^{\text {th }}\right.$ grade, 73 participants). The questionnaire for both of the grade level groups was the same, with minor adaptations since each group was using a different ELP. Both groups responded to 26 items, 16 multiple choice, 5 Likert scales and 5 open-ended items. In 2009, again, 73 upper-primary teachers (largely the same group as the year before, only $7 \%$ were new users) were surveyed using a modified version of the 2008 questionnaire. As the questionnaires are in Slovenian, they are not provided as appendices to this article (they can be obtained from the authors on request). The item stems have been translated into English, and are presented in bold print in the next section, grouped according to the research questions. The Likert scales are presented in their entirety. The analysis of all the quantitative and qualitative data obtained through the surveys sheds light on a number of variables involved in the pedagogical innovation represented by the ELP.

\section{RESULTS AND DISCUSSION}

\subsection{Context Data}

As both of the ELPs studied can be used in different primary school grades, the teachers were asked in which grades they chose to use them. The upper primary ELP was mostly used in the $8^{\text {th }}$ grade in $2008(49 \%)$, and in the $9^{\text {th }}$ grade in $2009(56 \%)$. The lower primary ELP was used mainly in the $5^{\text {th }}$ grade $(89 \%)$. In 2008 , the teachers were asked to state how many of their classes were using the ELP. Most teachers used it with only one of their classes (55\% upper primary, $67 \%$ lower primary). The average class size was 28 and 25 , respectively (with considerable variation).

In 2008, most of the teachers at both levels reported to have used the ELP at least once a month ( $72 \%$ and $54 \%$ respectively). The rest mostly used it at least once per trimester. Very few teachers used it on a weekly basis. In 2009, the situation was virtually the same.

How well were the teachers equipped to implement the ELP? In 2008, 78\% of the lower-primary teachers were satisfied with the Instructions for teachers. All of the participating lower primary teachers, and $85 \%$ of the upper primary teachers, attended special ELP training sessions. The majority found the training useful or very useful $(75 \%$, $19 \%$, and $65 \%, 25 \%$ respectively), and stated that they wished to attend it in the future, 
as well. The most frequently suggested topics were practical examples of successful ELP use, lesson planning and the integration of the ELP into the syllabus, and its use as a (formal) assessment tool.

\subsection{Perceived Quality of the ELP}

In response to the question of how well the ELP, as a whole, was adapted to the target learners, the teachers surveyed in 2008 rated their ELP on a scale of 1-5. As we can see, most ratings were high, self-assessment being the most problematic aspect for both lower and upper primary teachers.

\begin{tabular}{|l|c|c|c|c|}
\cline { 2 - 5 } \multicolumn{1}{l|}{} & $\begin{array}{l}\text { Average rating } \\
\text { upper-primary }\end{array}$ & SD & $\begin{array}{c}\text { Average rating } \\
\text { lower-primary }\end{array}$ & SD \\
\hline The content of the ELP is age-appropriate. & 4,10 & 0,65 & 4,17 & 0,62 \\
\hline The format of the ELP is age-appropriate. & 3,88 & 0,82 & 3,94 & 0,94 \\
\hline $\begin{array}{l}\text { The texts in the ELP are appropriate to the } \\
\text { learners' reading skills. }\end{array}$ & 3,75 & 0,97 & 4,00 & 0,84 \\
\hline $\begin{array}{l}\text { The self-assessment criteria are age- } \\
\text { appropriate. }\end{array}$ & 3,81 & 0,91 & 3,72 & 0,96 \\
\hline $\begin{array}{l}\text { The self-assessment criteria enable the } \\
\text { learners to realistically assess their knowledge. }\end{array}$ & 3,71 & 0,93 & 3,72 & 0,83 \\
\hline
\end{tabular}

Table 1: Perceived quality of the ELP - adaptation to learner level

As the ELP consists of three parts with somewhat separate functions, the teachers were also asked to rate the usefulness of each component. On a scale of $1-5$, the average rating by both groups was over 4 for all three, with the Dossier being rated as the most useful. In 2009, this item was changed to directly elicit the teachers' perceptions of the effectiveness of the ELP in its various functions. As the data below shows, the teachers deemed the ELP the most effective in its documenting function.

\begin{tabular}{|l|c|c|}
\hline The ELP... & $\begin{array}{c}\text { Average rating } \\
\text { upper-primary }\end{array}$ & SD \\
\hline ...is enjoyed in by the learners. & 3,95 & 0,62 \\
\hline ...helps learners to develop communicative competence. & 3,66 & 0,84 \\
\hline $\begin{array}{l}\text {...enables learners to appropriately document the FL competences } \\
\text { gained in school. }\end{array}$ & 4,36 & 0,7 \\
\hline $\begin{array}{l}\text {...enables learners to appropriately document the FL competences } \\
\text { gained outside of school. }\end{array}$ & 4,10 & 0,75 \\
\hline ...has a positive impact on the teacher-student rapport. & 3,75 & 0,78 \\
\hline ...encourages student-teacher dialogue. & 3,96 & 0,72 \\
\hline $\begin{array}{l}\text {...enables the learners' parents to gain quality, reliable information } \\
\text { on their child's foreign language competences. }\end{array}$ & 3,74 & 0,69 \\
\hline
\end{tabular}

Table 2: The effectiveness of the ELP in its various functions 
In 2008, two more specific items asked about the content of the ELP. In response to the questions of whether anything should be added to the ELPs they used and, if so, what, $33 \%$ of the lower primary teachers mostly suggested adding sample learner responses to the ELP rubrics. Of the upper primary teachers, only $13 \%$ suggested additions, ranging from minor technical improvements to a revision of the self-assessment scales. Another item inquired about the way language competence levels were defined in the ELP, since these are its central element. As many as $86 \%$ of the upper primary teachers, and $88 \%$ of the lower-primary teachers, felt they were well-defined and useful in the teaching process. The few teachers who responded to the open-ended question of how they could be improved said that the descriptors were not precise enough (4 answers) and that the scales should be simplified (4 answers).

\subsection{Perceived Effect on Teaching}

In 2008, the teachers were asked to assess the possible positive effects of the ELP on their teaching on a 5-point Likert scale. In Table 3, the two effects perceived as the most salient by both groups of teachers are highlighted.

\begin{tabular}{|l|c|c|c|c|}
\hline The ELP... & $\begin{array}{c}\text { Average rating } \\
\text { upper-primary }\end{array}$ & SD & $\begin{array}{c}\text { Average } \\
\text { rating lower- } \\
\text { primary }\end{array}$ & SD \\
\hline ...helps me in the classroom. & 3,62 & 0,77 & 3,94 & 0,54 \\
\hline $\begin{array}{l}\text {...supports more open formats of } \\
\text { instruction. }\end{array}$ & $\mathbf{3 , 8 6}$ & $\mathbf{0 , 8 2}$ & $\mathbf{4 , 0 0}$ & $\mathbf{0 , 6 9}$ \\
\hline $\begin{array}{l}\text {...helps me to present the learning } \\
\text { goals to the learners. }\end{array}$ & $\mathbf{3 , 8 5}$ & $\mathbf{0 , 7 6}$ & $\mathbf{4 , 1 7}$ & $\mathbf{0 , 8 6}$ \\
\hline $\begin{array}{l}\text {...enables me to set better quality } \\
\text { learning tasks and exercises. }\end{array}$ & 3,26 & 0,96 & 3,83 & 0,79 \\
\hline ...aids me with assessment and testing. & 3,33 & 0,90 & 3,33 & 0,84 \\
\hline ...enables more streamed instruction. & 3,60 & 0,88 & 3,72 & 0,83 \\
\hline $\begin{array}{l}\text {...brings more acknowledgment of the } \\
\text { mother tongue in FL learning. }\end{array}$ & 3,71 & 0,86 & 3,72 & 0,89 \\
\hline $\begin{array}{l}\text {...supports cross-curricular } \\
\text { connections. }\end{array}$ & 3,38 & 0,99 & 3,39 & 0,85 \\
\hline ...enables better planning of objectives. & 3,63 & 0,94 & 3,89 & 0,68 \\
\hline $\begin{array}{l}\text {...helps me make better teaching } \\
\text { methodology choices. }\end{array}$ & 3,33 & 0,88 & 3,50 & 0,71 \\
\hline
\end{tabular}

Table 3: The perceived effect of the ELP on teaching

In 2009, the upper primary teachers were asked to state whether the ELP had an effect on their instruction ( $66 \%$ said yes), and to provide descriptions of these effects. 
The answers were qualitatively analysed to reveal the main themes. The most frequent notion was self-assessment as a positive innovation (28 mentions). The comments actually do not always refer to teacher activity, but we assume that the teachers sometimes talk about their work through describing its effects on learners (e.g. "The students have begun thinking about their knowledge" and "Self-assessment has become easier and more systematic").

In the comments that clearly refer to changes in teacher activity, the most often mentioned issue is planning ( 9 comments, e.g. "I have rationalized the planning of an individual lesson" and "The aims have become more clearly defined" and "I linked the lesson aims to specific parts of the ELP"). Again, this is an issue that was dealt with by a separate survey item, but spilled over into related items, which confirms its centrality. The next most frequent comment was that the use of the ELP brought more variety into the lessons ( 7 comments), which was always seen as positive. In terms of lesson formats/methodology, the ELP brought about more independent learner activity ( 7 comments, e.g. "We devoted more time to individual work" and "The students did a great job with various writing projects to be placed into the ELP" and "The students began to look for persons and events to help with their language learning"). In terms of lesson content, there were individual comments on more work on receptive skills, more discussion of learning strategies, and more intercultural/ interlinguistic content. Even though only two teachers made this comment, it seems important to note that the ELP also has the potential to help a teacher get to know their students better ("I identified individual students' learning styles" and "I found out about their activities outside of school").

Since planning proved to be a key aspect of teaching affected by the introduction of the ELP in the 2008 survey, in 2009 the teachers were asked explicitly if, and in what ways, the use of the ELP affected their lesson planning. $62 \%$ said that their lesson planning was changed. In the 42 open-ended answers to the question about the type of changes, the mentioned issues included:

- time pressure (10 comments, e.g. "The lessons need to be planned more carefully, as there is not enough time to include work with the ELP"),

- official incorporation of the work with the ELP into the (annual) syllabus (8 comments),

- changes to the planning of teaching methods (7 comments, e.g. "I took more care to cater to different learning styles" and "I introduced more peer learning" and "I planned more individualization and ability streaming"),

- using the ELP at the ends of syllabus units (partly replacing or supplementing the usual revision and assessment activities, 5 comments),

- more planned self-assessment activities (4 comments),

- more focus on all four language skills (2 comments).

Some teachers reported, in detail, how they incorporated the ELP into their lessons (e.g. "I told the students to do their homework on a separate sheet, instead of in their notebooks, if it was to be included in the ELP"); this type of comment is less useful for a broader analysis, but valuable for ELP teacher training. 
Last but not least, one teacher's comment, although isolated, proves that it is possible to integrate the ELP into instruction to a much larger extent than was done by the majority of the participants: "I included the ELP into the phase of motivating my students, and into the phases of revising and assessment. The ELP has replaced many of the previous teaching/learning activities, and some of the learning materials, as well".

A special aspect of pedagogical innovations is whether, and to what extent, they require or encourage teachers to cooperate with each other. For this reason, the 2008 survey contained questions about the number of foreign language teachers (of different languages) working with each class using the ELP, and their teamwork. Since, at the lower primary level, students mostly take one foreign language class only, and the number of respondents in this group was low, we will only look at the upper level, where the most frequent situation involved 2 foreign language teachers teaching the same group of learners ( $42 \%$ ). $33 \%$ of the groups were taught by three or four teachers. Of those teachers who teach alongside at least one other FL teacher, $74 \%$ reported involving their colleagues into the work with the ELP, which was definitely a positive dissemination effect.

\subsection{Perceived Effect on Learning}

In 2008, the teachers were asked to assess the effect of the ELP on their learners, on a 5-point Likert scale. As Table 4 shows, the results from the two levels differ, but development of reflective thinking was rated highly in both groups.

\begin{tabular}{|l|c|c|c|c|c|c|}
\hline $\begin{array}{l}\text { When using the ELP, the } \\
\text { learners... }\end{array}$ & $\mathbf{n}$ & $\begin{array}{c}\text { Average rating - } \\
\text { upper primary }\end{array}$ & SD & $\mathbf{n}$ & $\begin{array}{c}\text { Average rating - } \\
\text { lower primary }\end{array}$ & SD \\
\hline $\begin{array}{l}\text {...are more motivated for FL } \\
\text { learning. }\end{array}$ & 73 & 3,55 & 0,83 & 17 & 4,29 & 0,59 \\
\hline $\begin{array}{l}\text {...have a more active role in } \\
\text { the learning process. }\end{array}$ & 73 & 3,81 & 0,79 & 18 & 4,22 & 0,73 \\
\hline $\begin{array}{l}\text {...take more responsibility } \\
\text { for their FL learning. }\end{array}$ & 73 & 3,62 & 0,92 & 18 & 3,78 & 0,65 \\
\hline $\begin{array}{l}\text {...develop reflective } \\
\text { thinking. }\end{array}$ & 73 & 3,99 & 0,54 & 18 & 4,00 & 0,69 \\
\hline $\begin{array}{l}\text {...are in more control of their } \\
\text { learning process. }\end{array}$ & 71 & 3,86 & 0,59 & 18 & 3,94 & 0,54 \\
\hline $\begin{array}{l}\text {...are more independent in } \\
\text { their FL learning. }\end{array}$ & 73 & 3,42 & 0,70 & 18 & 3,78 & 0,65 \\
\hline $\begin{array}{l}\text {...get quality feedback about } \\
\text { their learning process. }\end{array}$ & 72 & 3,88 & 0,65 & 18 & 3,94 & 0,54 \\
\hline
\end{tabular}

Table 4: The perceived effect of the ELP on learning

In another, open-ended item which asked about the effects of the ELP on teaching, a number of responses referred to the effects on the learners, most notably the 
development of self-assessment skills (e g. "The students can now assess themselves realistically"), increased motivation (e.g. "The students became more aware of the importance of learning foreign languages" and "The students were curious to see how they do and filled in the rubrics on their own" and "The students were surprised to see what they are already able to do, especially the weaker ones"), and the development of learner autonomy (e.g. "The ELP helped my students to find their learning style" and "The students can now set their own goals" and "The students think about language learning"). The value of the ELP as a record of learner achievement was also mentioned.

In the 2008 survey, there was a separate question about the effect of the ELP on learners' capacity for self-assessment. $78 \%$ of the upper-primary, and $66 \%$ of the lower-primary teachers said that their learners' self-assessments converged more with their own than before using the ELP.

Based on the results of the 2008 survey, in which the learner autonomy aspect of the ELP proved to be a challenge, the 2009 survey explicitly elicited information about the perceived effect of the ELP on various aspects of learner autonomy. As seen in Table 5, the ELP helped the teachers move towards more learner-centeredness, but true autonomy - setting one's own goals - still eludes almost a half of the participants.

\begin{tabular}{|l|c|c|c|c|}
\cline { 2 - 5 } \multicolumn{1}{l|}{} & \multicolumn{2}{c|}{ YES } & \multicolumn{2}{c|}{ NO } \\
\cline { 2 - 5 } \multicolumn{1}{l|}{} & $\begin{array}{c}\text { No. of } \\
\text { teachers }\end{array}$ & $\%$ & $\begin{array}{c}\text { No. of } \\
\text { teachers }\end{array}$ & $\%$ \\
\hline The learners set their own (individual) goals. & 43 & 59,7 & 29 & 40,3 \\
\hline $\begin{array}{l}\text { I and the learners define the necessary learning } \\
\text { steps together. }\end{array}$ & 69 & 95,8 & 3 & 4,2 \\
\hline $\begin{array}{l}\text { I use the ELP to talk to each student about their } \\
\text { progress. }\end{array}$ & 63 & 86,3 & 10 & 13,7 \\
\hline $\begin{array}{l}\text { I encourage learners to reflect on their learning in } \\
\text { writing. }\end{array}$ & 63 & 87,5 & 9 & 12,5 \\
\hline $\begin{array}{l}\text { I put written comments onto the learners' self- } \\
\text { assessments. }\end{array}$ & 54 & 74,0 & 19 & 26,0 \\
\hline
\end{tabular}

Table 5: The perceived effect of the ELP on learner autonomy

\subsection{Problems and Potential for Full-Scale Use}

In the 2008 survey, both groups of teachers were asked two overlapping open-ended questions about the problems they encountered in using the ELP. Only 5 teachers alltogether listed "negative effects", and 29 responded to "other problems in working with the ELP". In both items, the key issue was a lack of time to devote to the ELP, due to a packed syllabus. The second most common comment was that the ELP is too long/ demanding/complex for the learners (particularly the weaker ones). Other, individual responses ranged from content aspects (e.g. "Not enough clear linkage to curricular aims and content for each grade") to a lack of experience in working with the ELP 
and its technical details (e.g. "The folder cannot contain all the materials the learners collect over two years").

The teachers were also asked to respond to three general statements about the ELP. The answers show that the ELP is time-consuming and demanding to use, both issues that can be addressed in the future.

\begin{tabular}{|l|c|c|c|c|c|c|}
\hline $\begin{array}{l}\text { Working with } \\
\text { the ELP is... }\end{array}$ & $\mathbf{n}$ & $\begin{array}{c}\text { Average rating - } \\
\text { upper primary }\end{array}$ & SD & $\mathbf{n}$ & $\begin{array}{c}\text { Average rating - } \\
\text { lower primary }\end{array}$ & SD \\
\hline ...time-consuming. & 73 & 3,36 & 1,02 & 18 & 3,67 & 0,77 \\
\hline ...unnecessary. & 73 & 2,05 & 0,78 & 18 & 1,61 & 0,61 \\
\hline ...demanding. & 72 & 3,28 & 1,12 & 18 & 3,61 & 0,92 \\
\hline
\end{tabular}

Table 6: General evaluation of the ELP in 2008

A related question was whether the ELP should be integrated into the curriculum. As many as $89 \%$ of the lower primary teachers, and $78 \%$ of the upper primary teachers, said yes.

In the 2009 survey, the teachers were asked to respond to a different set of three statements concerning their feelings about the ELP. As Table 7 shows, the results mostly speak in favour of the ELP.

\begin{tabular}{|l|c|c|c|c|}
\cline { 2 - 5 } \multicolumn{1}{l|}{} & \multicolumn{2}{c|}{ YES } & \multicolumn{2}{c|}{ NO } \\
\cline { 2 - 5 } \multicolumn{1}{l|}{} & $\begin{array}{c}\text { No. of } \\
\text { teachers }\end{array}$ & $\%$ & $\begin{array}{c}\text { No. of } \\
\text { teachers }\end{array}$ & $\%$ \\
\hline $\begin{array}{l}\text { Does the ELP yield sufficient results, relative to } \\
\text { the investment? }\end{array}$ & 40 & 55,6 & 32 & 44,4 \\
\hline Would you recommend the ELP to other FL teachers? & 62 & 84,9 & 11 & 15,1 \\
\hline $\begin{array}{l}\text { Would you like to continue using the ELP in your } \\
\text { teaching? }\end{array}$ & 56 & 76,7 & 17 & 23,3 \\
\hline
\end{tabular}

Table 7: General evaluation of the ELP in 2009

A subquestion of whether the ELP should be made part of the curriculum was the question of whether it should be used as an obligatory assessment tool. In 2008, only $38 \%$ of the upper primary, and $42 \%$ of the lower primary teachers, felt that it should. In the 2009 survey, this question was changed, to make it more specific. As many as $77 \%$ of the upper primary teachers said that the ELP could not replace one of the existing forms of assessment. The question was supplemented with an open-ended item, asking which forms of assessment the ELP could replace, if any. The suggestions were:

- the ELP could be linked to oral testing (in different ways),

- the ELP could be used in descriptive assessment or as a supplementary grade,

- certain written products/worksheets in the ELP can be graded,

- the ELP can replace any/all other forms of assessment. 


\section{CONCLUSIONS}

The 2008 and 2009 teacher surveys on the use of the ELP in Slovenian primary schools were part of a formal piloting project which represented the third phase of introducing this innovation in Slovenia. Summarizing the results, we can draw three conclusions. Firstly, the two validated ELPs for Slovenian primary schoolers of two age brackets proved, in practice, to be quality materials: the average ratings were high for all the aspects of their content, presentation and effectiveness. The second main conclusion is that, in the teachers' judgement, the users were largely reaping all the benefits targeted by the creators of the ELP (see e. g. Skela 2012). For most teachers, the ELP changed their teaching by making it more varied, more communicative and learner-centred. It also facilitated the presentation of goals to the learners, and ushered in systematic learner self-assessment. The ELP's key positive impact on the learners was the increase of motivation at the lower level, and development of autonomy at the upper level, which is probably related to the greater cognitive maturity of the upper-primary learners. (While we did not statistically compare the 2008 results of the teacher groups at the two levels, due to their unequal sizes, this was, practically, the only point in which they differed noticeably). The teachers' positive reception of the ELP can further be seen from the fact that most of them disseminated it within their schools, wanted to continue using it, and felt that it should be introduced, across the board. These results are very positive and encouraging, despite the fact that the participating teachers were volunteers, early adopters who generally tend to embrace innovations.

The third main conclusion refers to the issues and problems with implementing the ELP. In our study, these were largely the same as those revealed by previous piloting studies in Slovenia and elsewhere, which testifies to the complexity and challenging nature of the innovation. Most teachers in our study chose to use the ELP in the upper grades of their bracket, probably because they considered it demanding, which was a fairly frequent open-ended comment. Self-assessment was the most difficult aspect for both levels, even though the scales were deemed to be well-designed. While most teachers felt that their learners' self-assessment skills nevertheless improved, the ability to set their own goals did not improve to the same extent. The documenting function of the ELP was rated by the teachers as more important than the pedagogical function - perhaps partly because it is less challenging, and thus more enjoyable for learners. Also, most teachers felt that the ELP could not be integrated into official assessment procedures.

Of course, to some extent these issues are related to practical factors, such as the degree of system support. In accordance with recommendations from previous studies, the teachers in our study were given well-attended and well-received training sessions. Despite that, most of them used the ELP in only one of their classes, and once a month on average, which is definitely related to workload and time constraints, the most frequently-reported implementation problem dealt with, in a variety of ways, by individuals in their lesson planning.

Most importantly, however, the results of the study show that the ELP, in a primary school context in Slovenia, is a complex pedagogical innovation, but one with great potential. Of its two parallel functions, the documenting of language learning and achievement 
is more readily embraced, while the self-assessment and self-directedness aspects involve a paradigm shift, which goes beyond the foreign language classroom. In this function, the ELP implementation would need to be sustained considerably longer, in order for its impact to fully unfold. Since the study presented in this article, the use of the ELPs in Slovenia has decreased, which has been a regrettable trend elsewhere in Europe, as well, due to a combination of factors, indicated already by Stoicheva et al. (2009: 5-7) and Little et al. (2011: 5). For the Slovenian context, Holc (2012: 94) lists the specific steps that should be taken, in order to further promote the use of the ELP at national level. We hope that this article will contribute to a revival in interest of all stakeholders in this excellent tool for the promotion of language and intercultural competences, and lifelong learning in general.

\section{Bibliography}

AMIČ, Irena/Nataša Elvira JELENC/Ana Marija MUSTER/Branka PETEK/Darja ŠKORJANC BRAICO/Tatjana ŽLINDRA (2010) Evropski jezikovni listovnik za odrasle. Ljubljana: Ministrstvo za šolstvo in šport RS; Založba Tangram.

Common European Framework of Reference for Languages: Learning, Teaching, Assessment (2001). Cambridge: Cambridge University Press.

CROMO (2007) CROMO: Medkulturni čezmejni modul - dopolnilo Evropskemu jezikovnemu listovniku 15+. Gradec/Trst/Ljubljana: Österreichisches Sprachen-Kompetenz-Zentrum; Agenzia Nazionale per lo Sviluppo dell'Autonomia Scolastica; Zavod Republike Slovenije za šolstvo. 7 July 2014. http://www.oesz.at/download/ publikationen/cromo_29_08_2007_slowenisch.pdf.

ČOK, Lucija/Neva ŠEČEROV/Suzana JELUŠČC GODINA/Nataša KRAGELJ/Anja MLAKAR/Nevenka ŠERGON OMAHEN (1999) Moja prva jezikovna mapa. Ljubljana: Pedagoška fakulteta UL; Ministrstvo za šolstvo in šport RS.

ČOK, Lucija/Neva ŠEČEROV/Janez SKELA/Anja ZORMAN (2011) Evropski jezikovni listovnik za osnovnošolce v starosti od 6 do 10 let. Ljubljana: Ministrstvo za šolstvo in šport RS.

DEUTSCH, Tomi (2008) Evropski jezikovni listovnik in Moja prva jezikovna mapa [unpublished report]. Ljubljana: Zavod RS za šolstvo.

DEUTSCH, Tomi (2009) Evropski jezikovni listovnik v osnovni šoli: Poročilo [unpublished report]. Ljubljana: Zavod RS za šolstvo.

EUROPEAN COMMISSION (1995) White paper on education and training: Teaching and learning, towards the learning society. Brussels: European Commission. 7 July 2014. http://aei.pitt.edu/1132/.

GODUNC, Zdravka (2012) "Evropski jezikovni listovnik v luči mednarodnih vrednot jezikovnega znanja." In: N. Holc (ed.), Evropski jezikovni listovnik v Sloveniji, 6068. Ljubljana: Zavod Republike Slovenije za šolstvo.

HOLC, Nada (2012) "Evropski jezikovni listovnik v slovenski šolski praksi - Rezultati projekta uvajanja in spremljave EJL v osnovni in srednji šoli." In: N. Holc (ed.), Evropski jezikovni listovnik v Sloveniji, 69-97. Ljubljana: Zavod Republike Slovenije za šolstvo. 
LITTLE, David/Radka PERCLOVÁ (2001) European Language Portfolio: Guide for Teachers and Teacher Trainers. Strasbourg: Council of Europe, Modern Languages Division.

LITTLE, David/Francis GOULLIER/Gareth HUGHES (2011) The European Language Portfolio: The Story So Far (1991-2011). Strasbourg: Council of Europe, Language Policy Division. 7 July 2014. http://www.coe.int/t/dg4/education/elp/elp-reg/ Source/Publications/ELP_StorySoFar_July2011_Final_EN.pdf.

MITCHELL, Rosamond (2009) "Foreign language teaching and educational policy." In: K. Knapp/B. Seidlhofer (eds), Handbook of Foreign Language Communication and Learning, 79-108 (Volume 6). Berlin: Walter de Gruyter GmbH \& C. KG, 79-108.

NEWBY, David/Rebecca ALLAN/Anne Brit FENNER/Barry JONES/Hanna KOMOROWSKA/Kristine SOGHIKYAN (2007) The European Portfolio for Student Teachers of Languages. Graz: Council of Europe. 7 July 2014. http://archive.ecml.at/ $\mathrm{mtp} 2 / \mathrm{fte} / \mathrm{pdf} / \mathrm{C} 3$ Epostl_E.pdf.

PUKLAVEC, Nada/Milka ENČEVA/Sabina MULEJ (2006) Evropski jezikovni listovnik za srednješolce $v$ starosti od 15 do 19 let. Ljubljana: Ministrstvo za šolstvo in šport; Založba Tangram.

SCHÄRER, Rolf (2000) European Language Portfolio: Final report on the pilot project. Strasbourg: Council of Europe, Modern Languages Division.

SCHÄRER, Rolf (2004) European Language Portfolio. From piloting to implementation 2001-2004. Strasbourg: Council of Europe, Language Policy Division. 7 July 2014. http://www.coe.int/t/dg4/education/elp/elp-reg/Source/History/ELP_report_2001_EN.pdf.

SCHÄRER, Rolf (2007) European Language Portfolio: Interim Report 2007. Strasbourg: Council of Europe. 7 July 2014. http://www.coe.int/t/dg4/education/elp/elp-reg/Source/History/ELP_report_2007_EN.pdf.

SCHNEIDER, Gunther/Peter LENZ (2001) European language Portfolio: Guide for Developers. Strasbourg: Council of Europe, Modern Languages Division.

SKELA, Janez/Metka ŠORLI/Nada HOLC (2000) Jezikovni listovnik za osnovnošolce. Maribor: Pedagoška fakulteta UL; Založba Obzorja.

SKELA, Janez/Nada HOLC (2006) Evropski jezikovni listovnik za osnovnošolce v starosti od 11 do 15 let. Ljubljana: Ministrstvo za šolstvo in šport; Tangram.

SKELA, Janez (2012) "Evropski jezikovni listovnik.” In: N. Holc (ed.), Evropski jezikovni listovnik v Sloveniji, 10-29. Ljubljana: Zavod Republike Slovenije za šolstvo.

STOICHEVA, Maria/Gareth HUGHES/Heike SPEITZ (2009) The European Language Portfolio: An impact study. Strasbourg: Council of Europe, Language Policy Division.

TROHA DOVŽAN, Ana/Bernarda LEVA/Bernarda KOSEM/Katja DRAGAR/Petra ZARANŠEK/Polona MIHALIČ/Simona KOŠČAK (2000) Evropska jezikovna mapa za študente. Ljubljana: Študentska organizacija Univerze v Ljubljani; Pedagoška fakulteta UL.

USHIODA, Emma/Jennifer RIDLEY (2002) Working with the European Language Portfolio in Irish post-primary schools: report on an evaluation project. CLCS Occasional Paper No. 61. Dublin: Trinity College, Centre for Language and Communication Studies. 


\section{Abstract \\ THE EUROPEAN LANGUAGE PORTFOLIO (ELP) IN SLOVENIAN PRIMARY EDUCATION: THE TEACHERS' PERSPECTIVE}

The European Language Portfolio (ELP) is a unique, pan-European language learning material, aimed at supporting life-long language learning and the development of learner autonomy and intercultural competences. The article outlines the ELP's origins, structure and functions, and its impact on foreign language learning and teaching in Europe. Of the Slovenian ELP models, the two intended for primary school have been the most widely-implemented. Their implementation was the subject of a three-year study, in the context of a national piloting project involving over 600 learners and 100 teachers, held in 2008 and 2009. Due to the complexity and scope of the study, this article focuses on the perspective of the teachers, as carriers of pedagogical innovation. The results show that the two versions of ELP validated for Slovenian primary schools are judged by the teachers as being quality materials which are well-adapted to the learners. This pilot period yielded a number of positive effects in both teaching and learning, most notably more communicative and learner-centered instruction formats, and an increase in the learners' motivation and self-assessment skills. The main concern was strained lesson planning, due to the fact that the ELP was not integrated into the curriculum. Overall, the study shows that, of the two parallel functions of the ELP, the documenting of language learning and achievement is more readily embraced, while the self-assessment and self-directedness aspects involve a paradigm shift, which would require further sustained and widely-supported implementation. This would enable the full unfolding of the ELP's great potential for the promotion of language and intercultural competences and lifelong learning in Slovenia and in Europe.

Keywords: European Language Portfolio (ELP), upper-primary, lower-primary, pilot study, teacher survey.

\section{Povzetek \\ EVROPSKI JEZIKOVNI LISTOVNIK (EJL) V SLOVENSKEM OSNOVNEM ŠOLSTVU: PERSPEKTIVA UČITELJEV}

Evropski jezikovni listovnik (EJL) je edinstveno evropsko gradivo za učenje jezikov, namenjeno podpori vseživljenjskega učenja jezikov in razvijanju avtonomije učenca in njegovih medkulturnih zmožnosti. Članek predstavi razvoj Listovnika, njegovo zgradbo in funkcije ter vpliv na učenje in poučevanje tujih jezikov v Evropi. Od modelov Listovnika, razvitih v Sloveniji, sta bila do sedaj najširše uporabljena dva za osnovno šolo. Njuna vpeljava je bila predmet triletne raziskave $\mathrm{v}$ kontekstu pilotiranja na nacionalni ravni, $\mathrm{v}$ katerem je v letih 2008 in 2009 sodelovalo več kot 600 učencev in 100 učiteljev. Zaradi obsega in kompleksnosti pridobljenih podatkov se članek osredotoča na perspektivo učiteljev kot nosilcev pedagoške inovacije. Rezultati kažejo, da dva modela EJL, validirana za slovenske osnovne šole, učitelji ocenjujejo kot kvalitetna gradiva, dobro prilagojena 
potrebam učencev. Njuno pilotiranje je $\mathrm{v}$ očeh učiteljev dalo vrsto pozitivnih učinkov, predvsem bolj komunikacijski in na učenca osredinjen pouk ter povečanje motivacije in sposobnosti samoocenjevanja pri učencih. Glavni problem je bil težavno načrtovanje pouka, ker EJL ni vključen v učni načrt. V splošnem rezultati kažejo, da je od dveh vzporednih funkcij EJL lažje sprejeto dokumentiranje procesa in dosežkov učenja jezikov, medtem ko tisti njegovi vidiki, ki se tičejo avtonomije učenja, zahtevajo spremembo miselnosti, za katero je potrebna daljša kontinuirana in podprta vpeljava. Ta bi omogočila polno doseganje velikega potenciala EJL za spodbujanje jezikovnih in medkulturnih zmožnosti ter vseživljenjskega učenja v Sloveniji in v Evropi.

Ključne besede: Evropski jezikovni listovnik (EJL), osnovna šola, druga triada, tretja triada, pilotna študija, anketa učiteljev. 